\title{
SOSIALISASI DAN PENYULUHAN KESEHATAN MASYARAKAT DI RW 19 KELURAHAN TANJUNG UNCANG
}

\author{
PUBLIC HEALTH SOCIALIZATION AND COUNSELING \\ AT RW 19 TANJUNG UNCANG VILLAGE
}

\author{
Agus Umar Ryadin \\ Teknik Mesin, FakultasTeknik, Universitas Riau Kepulauan, Indonesia \\ agusumar@ft.unrika.ac.id
}

\begin{abstract}
Abstrak
Kegiatan Pengabdian Masyarakat kali ini dilaksanakan di RW 19, Kelurahan Tanjung Uncang, Kecamatan Batu aji, Kota Batam. Berdasarkan kondisi wilayahnya, daerah ini merupakan lingkungan warga yang menempati lahan kosong milik perseorangan ataupun perusahaan yang belum digunakan, yang biasa dikenal sebagai Ruli (Rumah Liar). Dilihat dari lingkungan tempat tinggalnya yang sebahagian besar adalah lahan kosong dimana tidak tersedianya fasilitas air bersih dan saluran pembuangan air (toilet) yang memadai, kebersihan lingkungan yang tidak dikelola dengan baik, dan beberapa hal penting lainnya, maka potensial permasalahan yang dapat timbul salah satunya adalah masalah kesehatan masyarakat, baik yang disebabkan oleh factor lingkungan maupun factor manusianya. Untuk itulah salah satu solusi yang tepat sebagai langkah awal untuk peningkatan kesehatan masyaraka tadalah dengan mengadakan Sosialisasi dan Penyuluhan Kesehatan Masyarakat, khususnya kepada warga RW 19, dalam ha lini adalah tentang Pentingnya Hidup Bersih dan Sehat, yang dijabarkan dalam "10 Perilaku Hidup Bersih dan Sehat (PHBS) di RumahTangga", Dengan mengetahui hal-hal tersebut, diharapkan warga masyarakat dapat menerapkannya di dalam lingkungan rumah tangganya masing-masing sehingga tingkat kesehatan masyarakat bias menjadi lebih baik. Dengan meningkatnya tingkat kesehatan masyarakat maka kesejahteraannya pun dapat menjadi lebih baik.
\end{abstract}

Kata Kunci; Bersih, Sehat, Masyarakat, Lingkungan, Rumah Tangga.

\begin{abstract}
Community Service Activities was held in RW 19, TanjungUncang Village, Batuaji District, Batam City. Based on the conditions of its territory, this area is a neighborhood of citizens who occupy vacant land owned by individuals or companies that have not been used, commonly known as Ruli (Rumah Liar). Viewed from the neighborhood where most of the abandoned are vacant land where there is not enough clean water and sanitary facilities, cleanliness of environment that is not well managed, and some other important things, the potential problems that can arise one of them is public health problems, whether caused by environmental factors or human factors. For this reason one of the right solutions as a first step for improving public health is by holding Socialization and Public Health Counseling, especially to RW 19 residents, in this case is about the Importance of Clean and
\end{abstract}


Healthy Life, which is described in "10 Behavior Clean and Healthy Living (PHBS) in Housewifery ",By knowing those things, it is expected that community members can apply them in their respective housewifery so that the level of public health can be better. By the increasing level of public health then their welfare also can be better.

Keywords; Clean, Healthy, Society, Environment, Housewifery.

\section{PENDAHULUAN}

Sebagai salah satu bagian dari Tri Darma Perguruan Tinggi, khususnya untuk Dosen, Pengabdian pada Masyarakat adalah kegiatan yang dapat memberikan manfaat kepada semua pihak, baik kepada Dosen itu sendiri, Perguruan Tinggi maupun kepada Masyarakat. Adapun manfaat untuk Dosen adalah dapat secara langsung mempelajari dan mengamati hal-hal yang dibutuhkan oleh masyarakat berkaitan dengan tingkat kehidupan dan latar belakang masyarakat tersebut. Sehingga dengan begitu dapat dicari ide-ide baru yang dapat dikembangkan melalui penelitian ilmiah Dosen sesuai dengan jenis keilmuannya masingmasing.

Masyarakat di Kota Batam ini terdiri dari masyarakat yang sangat majemuk, yang sebagian besar merupakan masyarakat pendatang yang berasal dari hamper semua daerah yang ada di Indonesia, baik dariJawa, Sumatra, Nusa Tenggara, Sulawesi, ataupun daerahdaerah lainnya di Indonesia. Masyarakat tersebut tinggal dan tersebar merata mulai dari perumahan-perumahan maupun rumah liar atau yang sering dikenal sebagai Ruli.

Kegiatan Pengabdian Masyarakat kali inidilaksanakan di lingkungan RW 19, Kelurahan Tanjung Uncang, Kecamatan Batuaji, Kota Batam. Berdasarkan kondisi wilayahnya, daerah ini merupakan lingkungan warga yang tinggal dan menempati lahan kosong milik perseorangan ataupun perusahaan yang belum digunakan, yang biasa dikenal sebagai Ruli (maaf, Rumah Liar). Sebagaimana umumnya lingkungan Ruli, lokasi ini tidakdilengkapi dengan sarana air bersih yang berasal dari ATB (Adhya Tirta Batam), sehingga warga pada umumnya hanya memanfaatkan air tadah hujan, yang ditampung di kolam-kolam atau bak-bak penampungan yang mereka buat sendiri di sekitar rumah mereka.

Dilihat dari kondisi penduduknya yang berjumlah 528 jiwa dimana sebagian besar merupakan usia bekerja/produktif $(51 \%)$ dan usia sekolah (35\%), faktor kesehatan adalah hal yang sangat penting untuk diperhatikan karena akan sangat mempengaruhi kesempatan dan kemampuan mereka untuk dapat melanjutkan sekolah dan pekerjaannya sehari-hari. Tentu 
saja kesehatan tidak hanya terfokus kepada mereka saja tetapi juga kepada seluruh warga masyarakat yang ada di RW 19 tersebut karena kesehatan adalah hak yang paling mendasar bagi semuaumat manusia.

\section{Permasalahan}

Dilihat dari lingkungan tempat tinggal warga RW 19 kelurahan Tanjung Uncang Kecamatan Batuaji Kota Batam, yang sebahagian besar adalah lahan kosong dimana tidak tersedianya fasilitas air bersih dan saluran pembuangan air (toilet) yang memadai,kebersihan lingkungan yang tidak dikelola dengan baik, dan beberapa hal penting lainnya, maka potensial permasalahan yang dapat timbul salah satunya adalah masalah kesehatan masyarakat, baik yang disebabkan oleh faktor lingkungan maupun faktor manusianya.

\section{METODOLOGI}

\section{Bentuk kegiatan}

Berkaitan dengan hal tersebut di atas dan juga sehubungan dengan program Pemerintah untuk menggalakkan pentingnya menjaga kesehatan masyarakat, maka salah satu solusi yang tepat sebagai langkah awal untuk peningkatan kesehatan masyarakat adalah dengan mengadakan Sosialisasi dan Penyuluhan Kesehatan Masyarakat,dalam hal ini adalah tentang Pentingnya Hidup Bersih dan Sehat, khususnya kepada warga RW 19 Kelurahan Tanjung Uncang, Kecamatan Batuaji, Kota Batam.

\section{Teknis Pelaksanaan}

Untuk Teknis Pelaksanaannya adalah dengan bekerja sama dengan Ketua RW 19, Bapak Arsad Ara dan para Ketua RT yang ada di lingkungan RW 19 (RT $01 \sim$ RT 03) untuk mengadakan Sosialisasi dan Penyuluhan Kesehatan Masyarakat dengan mengundang seluruh Warga RW 19, baik orangtua maupun anak-anak. Adapun sebagai narasumbernya adalah Bapak dr. Adi Yusal Sastrawan, seorang dokter umum di Batam.

\section{Waktu Pelaksanaan}

Kegiatan ini dilaksanakan pada hari Sabtu dan Minggu, tanggal 26 dan 27 Agustus 2017, mulai jam 10.00 pagi sampai 12.30 siang, bertempat di depan Rumah Ketua RW 19. Adapun persiapan acaranya, dimulai dari penyampaian undangan ke seluruh Warga RW 19, kemudian dilanjutkan dengan persiapan tempat acara yaitu tenda yang dibangun secara swadaya dan kerjasama dari Warga RW 19 itu sendiri, dilakukan sejak hari jum'at, tanggal 25 Agustus 2017. Selain itu, kegiatan ini didukung langsung oleh para sejumlah Mahasiswa 
yang berasala dari berbagai fakultas dan program studi yang terdiri dari 25 (dua puluh lima) orang Mahasiswa.

\section{PEMBAHASAN}

\section{Suasana Kegiatan}

Acara Sosialisasi dan Penyuluhan Kesehatan Masyarakat ini dihadiri oleh beberapa Warga RW 19 yang hadir bersama keluarganya, termasuk anak-anak yang sangat antusias mengikuti acara tersebut sejak awal. Termasuk di dalamnya juga hadir para tokoh masyarakat dan tokoh agama di lingkungan RW 19.

\section{Keterlibatan Mitra}

Pelaksanaan kegiatan ini sangat didukung oleh seluruh warga RW 19, termasuk para tokoh masyarakat dan tokoh agama, khususnya Ketua RW 19, Bapak Arsad Ara, dan para Ketua RT di lingkungan RW 19, yaitu RT 01 - RT 03. Ini ditunjukkan dengan sambutan dan keterlibatan warga RW 19 untuk bersama-sama membangun tenda dan menyiapkan kursikursi untuk digunakan pada kegiatan ini, serta kehadiran dan partisipasinya dalam kegiatan tersebut.

\section{Hasil yang Dicapai}

Dari hasil pengamatan yang kami lakukan, masyarakat yang hadir sangat antusias dan menyimak materi Sosialisasi dan Penyuluhan Kesehatan Masyarakat yang diberikan oleh Nara sumber yaitu dr. Adi Yusal Sastrawan. Adapun materi Sosialisasi dan Penyuluhan Kesehatan Masyarakat yang dibawakan oleh dr. Adi Yusal Sastrawan adalah tentang Pentingnya Hidup Bersih dan Sehat yang terdiri dari "10 Perilaku Hidup Bersih dan Sehat (PHBS) di RumahTangga" merupakan hal penting yang dapat mempengaruhi kesehatan masyarakat khususnya di lingkungan rumahtangga. Materi tersebut dijabarkan secara sederhana dan dengan bahasa yang mudah dimengerti oleh para Warga yang hadir, juga didukung oleh adanya lembar petunjuk berupa gambar-gambar untuk masing-masing 10 hal tersebut.

Berikut beberapa hal penting tentang "10 Perilaku Hidup Bersih dan Sehat (PHBS) di RumahTangga":

a) PHBS di Rumah Tangga adalah upaya untuk memberdayakan anggota rumah tangga agar tahu, mau dan mampu melaksanakan perilaku hidup bersih dan sehat serta berperan aktif dalam gerakan kesehatan di masyarakat. 
b) PHBS di RumahTangga dilakukan untuk mencapai Rumah Tangga Sehat.

c) RumahTangga Sehat adalah rumah tangga yang melakukan 10 PHBS di RumahTangga yaitu :

1. Persalinan ditolong oleh tenaga kesehatan

2. Memberi bayi ASI eksklusif

3. Menimbang bayi dan balita

4. Menggunakan air bersih

5. Mencuci tangan dengan air bersih dan sabun

6. Menggunakan jamban sehat

7. Memberantas jentik di rumah

8. Makan buah dan sayur setiap hari

9. Melakukan aktivitas fisik setiap hari

10. Tidak merokok di dalam rumah

Dengan mengetahui hal-hal tersebut, diharapkan warga masyarakat dapat menerapkannya di dalam lingkungan rumah tangganya masing-masing sehingga tingkat kesehatan masyarakat bisa menjadi lebih baik. Karena hanya dengan tingkat kesehatan yang lebih baik maka kesejahteraan masyarakat dapat menjadi lebih meningkat, khususnya warga masyarakat di lingkungan RW 19.

Tabel.1. Data Kelompok Usia Warga RW 19 Kelurahan Tanjung Uncang, Batam

\begin{tabular}{lcc}
\hline Type & Jumlah & Persentase \\
\hline a) Balita & 59 & $11.17 \%$ \\
b) Usia 6 18 tahun & 139 & $26.33 \%$ \\
c) Usia 19 25 tahun & 46 & $8.71 \%$ \\
d) Usia 26 55 tahun & 268 & $50.76 \%$ \\
e) Usia 55 tahunkeatas & 16 & $3.03 \%$ \\
\hline Total & $\mathbf{5 2 8}$ & $\mathbf{1 0 0 \%}$ \\
\hline
\end{tabular}

Selain itu, dalam acara tersebut juga dibagikan bubuk ABATE secara gratis untuk masing-masing rumah tangga yang dapat digunakan untuk mencegah penyebaran dan perkembangbiakan nyamuk Aedes Aegypti sebagai hewan penyebar penyakit Demam Berdarah. 


\section{KESIMPULAN}

Dari pelaksanaan acara Penyuluhan Pentingnya Kesehatan Masyarakat ini, adalah suatu kegiatan yang positif dan penting. Khususnya bagi Warga RW 19 yang selama ini merasa jarang dikunjungi oleh pihak yang berwenang ataupun instansi pemerintahan, baik tingkat Kelurahan maupun tingkat pemerintahan yang lebih tinggi.

\section{REFERENSI}

LPPM UNRIKA, 2017. Buku Pedoman Kuliah Kerja Nyata (KKN) Universitas Riau Kepulauan (UNRIKA) Batam Tahun 2017. Batam, LPPM URIKA.

Arsad Ara. 2017. Detail Data Penduduk Warga RW 19 Kelurahan Tanjung Uncang, Kecamatan Batuaji, Kota Batam.Batam

Kementerian Kesehatan Republik Indonesia. 2017. 10 Indikator Perilaku Hidup Bersih dan Sehat (PHBS) di RumahTangga. 